\title{
The Potential in Water Supply and Sanitation Services of the On Site Production of Sodium Hypochlorite (OSEC) Driven by PV Solar Source
}

\author{
Andrea Micangeli", Emanuele Michelangeli, Vincenzo Naso, Nicola Iannuzzo \\ Interuniversity Centre of Research on Sustainable Development - CIRPS \\ "Sapienza" University of Rome \\ e-mail: andrea.micangeli@uniroma1.it
}

\begin{abstract}
Cite as: Micangeli, A., Michelangeli, E., Naso, V., Ianuzzo, N., The Potential in Water Supply and Sanitation Services of the On Site Production of Sodium Hypochlorite (OSEC) Driven by PV Solar Source, J. sustain. dev. energy water environ. syst., 1(4), pp 311-325, 2013, DOI: http://dx.doi.org/10.13044/j.sdewes.2013.01.0024
\end{abstract}

\begin{abstract}
This study aims at evaluating the impact of an On Site Electro Chlorination (OSEC) device, a system for the sodium hypochlorite production, on the improvement of health and hygienic standards in Mesoamerica focusing on Chiapas-Mexico and Costa Rica, as well as in Africa, Western Sahara (Refugees Camp) and Tanzania. The threat of infectious diseases and the importance of cleaned and treated water with the consequent high impact on the vulnerable population have been studied in each of the above countries. In this framework the production of low cost sodium hypochlorite through a stand-alone system powered by PV solar source could be a good starting point in improving sanitation conditions, assuring the disinfection of water and clothes, and improve food safety. The cost analysis shows that producing sodium hypochlorite with an OSEC solar system could lead to 10 to 15 times saving with respect to the purchasing of it at market price, above all in developing countries. Furthermore, the LCA study highlights the low environmental impact of the on-site production of sodium hypochlorite through qualitative and quantitative data that demonstrate how this system has pollutant emissions from 14 to 56 times lower than the equivalent industrial process ( $\mathrm{N}$ factor). The paper describes as well possible practical applications of the sodium hypochlorite in the African and Latin American context. Additionally, it demonstrates the potential to create an impact on the social context and microenterprises specialised in the production of hygiene and sanitation products, managed by local people selling at affordable prices and reaching the poorest villages of developing countries.
\end{abstract}

\section{KEYWORDS}

Clean Water Technologies, On Site Electro Chlorination (OSEC), LCA, Photovoltaic System.

\section{INTRODUCTION}

In developing countries, the construction and management of water treatment plants is one of the most diffused problems. The poor understanding of the importance of the quality of water is another existing aspect and consequently water treatment is often inadequate and unreliable. Moreover the lack of trained and specialized personnel able to maintain and manage this kind of system is another recurrent problem to be considered. There are several technological solutions for water treatment but the appropriate choice can be taken only after an accurate analysis of all involved aspects, such as social, economic and technical. These are the reasons why technologies used have to be simple, affordable and sustainable.

\footnotetext{
* Corresponding author
} 
Sodium Hypochlorite $(\mathrm{NaOCl})$ is a powerful germicide able to remove $99.9 \%$ of bacteria, viruses, protozoa and fungal agents: it is used for disinfection (wounds, surfaces, clothing, bed sheets, towels, dishes...), water purification, and food cleaning such as fruits and vegetables. Provided that the physical and chemical quality of the water is acceptable, disinfection by Sodium Hypochlorite provides the most effective mean for reducing the numbers of microorganisms in drinking water. At present chlorination is the most and widely applied in treating community water supplies [1,2].

In remote and rural locations, the option of on-site production of Sodium Hypochlorite can be the long term and sustainable solution. In details, the process called OSEC (On Site Electro Chlorination) is a system able to produce on site Sodium Hypochlorite from sea water or from concentrated aqueous solution of Sodium Chloride $(\mathrm{NaCl})$ through the process of electrolysis powered by a PV solar source. The uses of Sodium Hypochlorite are so comprehensive that the technology for the production on site from solar photovoltaic source (PV) can contribute effectively to the needs of hygiene and health products of small rural and peri-urban low-income communities [3-7] and to the needs of people in emergency situations [8-10].

The importance of microfinance to address the financing gap in water supply and sanitation services has been recognized in several recent reports and workshops $[3,12]$. The potential of microfinance in meeting the financial needs of poor and low income groups for improved access to a higher quality of water and sanitation services has been stated. Despite this, there has not been any assessment of the potential size and scope of this market for microfinance and microenterprise [13].

The social and environmental objectives are compatible with economic prosperity. It is interesting to note that the link between these objectives, seemingly contradictory, is to be found in innovation. Giving a look to the experiences of social entrepreneurs around the world, their distinctive features are the ability to see opportunities and applications in places and markets in the world where no one would invest, adapt new technologies and innovative approaches to provision in contexts which seem unprepared to accept them, not to stop at the paddocks of what is commonly referred to business but to have the courage to take risks [14].

One of the most important blocks to go ahead with this vision is the transition from the advantages of economies of scale to a system based on the quality and production of goods and services that respond effectively to the improvement of the quality of life of people and improving the use of environment and natural resources.

Many studies demonstrate the direct relationship that exists between the improvement of general economic conditions of households and improvement in their health conditions. This shows that providing people with economic instruments and technologies to create their own business has a social and cultural impact much greater than simple one-off loans $[15,16]$.

The experiences of microenterprise applied to the supply of drinking water and water infrastructure have made possible to reach several targets simultaneously. On the contrary, often, government investments in major water infrastructure or in pipe-water supply do not automatically translate into improved health conditions and take an enormous amount of economic resources that could be employed more effectively [17]. This shows how essential it is to analyse the needs of affected areas in order to implement technologies that would meet more efficiently and effectively the needs of affected populations and to create an integrated program of water, sanitation, nutrition, health care and health education [18-20].

The OSEC system that the CIRPS, Interuniversity Research Centre for Sustainable Development, is studying operates in batch mode. A $50 \mathrm{~L}$ tank is filled with a $3 \%$ Sodium 
Chloride solution, where the electrolytic cell is immersed. In 5 hours a Sodium Hypochlorite solution is produced with an equivalent chlorine concentration of $8 \mathrm{~g} / \mathrm{L}$. A recent experimental study revealed the possibility to recover the hydrogen produced during the electrolytic process and store it in a fuel cell allowing, with the PV panels, a complete self-alimentation of the OSEC until 15 hours a day with a 150 litres production of Sodium Hypochlorite solution.

The comparative advantages of implementing the OSEC system in a village of a developing country (in spite of common commercial solutions) are various:

- The problems of fuelling the system are avoided because hypochlorite is produced by solar energy;

- The problems associated with transport and storage of Sodium Hypochlorite solution are avoided;

- The problems of dependence on external suppliers are avoided;

- The product is always available, and it can be produced according to the needs of the users;

- The product does not require chemical additives for the oxidation of pathogens.

Increasing the dissemination and use of this product could have very positive consequences on the living conditions of the populations considered in this study.

\section{FIELD APPLICATIONS AND ENVIRONMENTAL IMPACT OF OSEC: QUALITATIVE ANALYSIS}

In many areas of Africa and Latin America the problems of access to drinking water and the improvement of the general health conditions are still far from being solved.

Much of the most common communicable and infectious diseases, such as typhoid, cholera, salmonellosis and enterocolitis are transmitted via water and caused by the lack of basic health care practices. The population groups most affected by the lack of adequate hygienic conditions are women, before and after childbirth and children under five years of age. [21-23]

Other diseases, such as malaria and dengue, that affect countries such as Chiapas, the rural areas of Costa Rica and Tanzania, could see reduced their dissemination as a result of better treatment of the water cycle and improvements in sanitary conditions both individually and at a community level [24, 25]. In order to assess the effectiveness and the applicability of an OSEC system in Africa and Latin America, indicators have been identified. Tables 1 and 2 compare various indicators for each country considered (Tanzania and Western Sahara for Africa, Mexico and Costa Rica for Central and Latin America).

Table 1. Health and socio-economic indicators

\begin{tabular}{|c|c|c|c|c|c|c|}
\hline & $\begin{array}{c}\text { Health Status } \\
\text { (life } \\
\text { expectancy at } \\
\text { birth) } \\
\text { [years] }\end{array}$ & $\begin{array}{c}\text { Infant } \\
\text { mortality } \\
\text { rate }\end{array}$ & $\begin{array}{c}\text { Sanitation } \\
\text { levels } \\
\text { (proportions of } \\
\text { population } \\
\text { having access to } \\
\text { water supply) } \\
{[\%]}\end{array}$ & $\begin{array}{c}\text { Socioeconomic } \\
\text { status } \\
\text { (adult literacy } \\
\text { rate) } \\
\text { [\% age } 15 \text { and } \\
\text { over can read } \\
\text { and write] } \\
\end{array}$ & $\begin{array}{c}\text { Population } \\
\text { below } \\
\text { poverty line } \\
{[\%]}\end{array}$ & $\begin{array}{c}\text { Proportion of } \\
\text { the } \\
\text { population } \\
\text { using } \\
\text { improved } \\
\text { sanitation } \\
\text { facilities } \\
{[\%]} \\
\end{array}$ \\
\hline $\begin{array}{l}\text { Chiapas, } \\
\text { Mexico }\end{array}$ & 74.4 & 21.7 & 74 & 61 & 44.2 & 92 \\
\hline Costa Rica & 79.9 & 9.4 & 97 & 94.9 & 16 & 95 \\
\hline Tanzania & 52.9 & 66.9 & 54 & 69.4 & 36 & 24 \\
\hline $\begin{array}{l}\text { Western } \\
\text { Sahara }\end{array}$ & 61.1 & 60.4 & n.a. & n.a. & n.a. & n.a. \\
\hline
\end{tabular}


Table 2. Table of Diseases

\begin{tabular}{|c|c|c|c|c|c|}
\hline & Degree of risk & $\begin{array}{c}\text { Food or waterborne } \\
\text { disease }\end{array}$ & $\begin{array}{c}\text { Vector } \\
\text { borne } \\
\text { diseases }\end{array}$ & $\begin{array}{c}\text { Water } \\
\text { transmitted } \\
\text { diseases } \\
\end{array}$ & $\begin{array}{l}\text { Animal } \\
\text { contact } \\
\text { diseases }\end{array}$ \\
\hline $\begin{array}{l}\text { Chiapas, } \\
\text { Mexico }\end{array}$ & Intermediate & $\begin{array}{c}\text { Bacterial diarrhoea, } \\
\text { Hepatitis A, Typhoid } \\
\text { fever }\end{array}$ & $\begin{array}{l}\text { Dengue } \\
\text { fever }\end{array}$ & $\begin{array}{l}\text { Leptospirosis } \\
\text { (Mexico) }\end{array}$ & \\
\hline $\begin{array}{l}\text { Costa } \\
\text { Rica }\end{array}$ & Intermediate & Bacterial diarrhoea & $\begin{array}{l}\text { Dengue } \\
\text { fever }\end{array}$ & & \\
\hline Tanzania & Very High & $\begin{array}{l}\text { Bacterial diarrhoea, } \\
\text { Hepatitis A, Typhoid } \\
\text { fever }\end{array}$ & $\begin{array}{l}\text { Malaria, } \\
\text { Plague }\end{array}$ & Schistosomiasis & Rabies \\
\hline $\begin{array}{l}\text { Western } \\
\text { Sahara }\end{array}$ & \multicolumn{5}{|c|}{ Not available } \\
\hline
\end{tabular}

The indicators were chosen for their ability to provide, to the highest level possible of accuracy, a picture of health, water supply and socio-economic profile characterizing each country.

The data reveal that the general condition of the countries of the Pacific region is far superior to that of African countries. However, the percentages in the first case refer to the country-system and do not show any fluctuations and differences that occur in some rural and peri-urban areas [26-28].

It is essential to consider socio-economic indicators since many international studies [29-30] show that the success of interventions in water supply and, in general, aimed at improving health conditions, depends largely on the socio-economic spectrum.

Analysis about the results of water supply projects show that below a certain threshold of literacy and social awareness, actions in the field of water and sanitation are not getting the desired results [6].

For the purpose of our study, it is therefore essential to take into account socio-economic variables in order to identify how OSEC technology can bring real benefits to low-income populations of the four countries taken into consideration.

Countries have been selected on the basis of the possibility to install the OSEC technology powered by PV solar source. In all four countries a device has been installed (Chiapas, Western Sahara, Tanzania) or is being under feasibility study (Costa Rica).

In Chiapas, the OSEC technology has been realized in the community La Realidad. La Realidad, located in the region of the Selva Lacandona, belongs to the municipality of Las Margaritas. The most common diseases are anaemia, malnutrition, gastritis, intestinal and skin infections, and respiratory difficulties. The initiative has solved the problem of disinfection (food, hygiene, health, and clothing) through the use of Sodium Hypochlorite, already widely used by indigenous people, but they were buying it and paying 6 pesos for a pint. The project has allowed us to produce a sufficient amount of hypochlorite and make it available to the community at a lower price because the only real cost was the salt needed to operate the machinery.

In Western Sahara the OSEC installation allowed to respond to difficult conditions even worse than in the case of Chiapas. This confirms the difficulty, as demonstrated in Tables 1 and 2 to find even the exemplary data of the general conditions of the Saharawi people. The conflict affecting people of Western Sahara since 36 years, the poor hygienic conditions in refugee camps, widespread unemployment and the difficulty in finding drinking water resources due to climatic conditions have also prevented an effective socio-economic development. Once again the OSEC technology has allowed us to 
produce on-site Sodium Hypochlorite at low cost to assure drinkable water and various uses in sanitation [31].

Currently in Costa Rica, there is in act a feasibility study to install the OSEC technology in a cooperative named CoopeSilencio located in a rural area of Western Pacific. El "Silencio" project is an answer to the closed commercial policy, made 27 years ago, by a large fruit and vegetable production company who left without job the rural population in Quepos. El "Silencio" allows the cooperative to provide work and prevent the depopulation of the area. This is a structure dedicated to sustainable tourism where tourist services are accompanied as well as palm oil production and management of a natural reserve.

The OSEC technology will enable CoopeSilencio to have considerable savings, since the chlorine can be produced on site, purchased at prices much more affordable. In addition, tourism business needs large amounts of disinfectants for cleaning the rooms and detergents to wash clothes, sheets and dishes. The increasing attention to environmentally sustainable tourism, in course of development in South American countries, makes such a technology particularly attractive, since it does not consume electricity, does not produce polluting waste and permits concrete savings in respect to the purchase of the product on the market.

In Tanzania an OSEC system has been installed in the schools of Hai District (Kilimanjaro Region).

The schools have been chosen based on the following criteria:

- distance from the electrical network;

- critical need of electricity;

- existence of water sources that cannot be used at present (distance or poor quality of water).

The project included the installation of innovative prototypes, already tested and experimented at the Faculty of Engineering of "Sapienza"- University of Rome (CIRPS' laboratories) in connection with problems related to: lack of electricity; lack of drinking water; lack of domestic hot water [32].

The project will provide the school in Longoi with a photovoltaic power plant. The electricity produced by this plant will supply lighting of classrooms and local residences, as well as electricity for OSEC, in order to purify drinking water. Additionally, in order to get energy (the electricity price is becoming more and more expensive [33]), it will recover hydrogen that is usually a waste product of OSEC process [34]. The challenge of this project has been to involve the students not only in terms of renewable energies but also in terms of enterprise creation. For this reason, visits to already operating enterprises have been planned.

\section{ENVIRONMENTAL IMPACT OF A SELF- PRODUCTION PROCESS ON SITE}

In order to obtain beneficial results from the use of OSEC in the countries above mentioned, we have carried out a study on the environmental impact of the process, as one of the biggest advantages of this technology is the low environmental impact on the operation. In fact the polluting emissions of a technology on site are much lower than those of an industrial production.

We can tackle the problem of emissions with the methodology LCA: the Life Cycle Assessment is defined as "an objective procedure for the evaluation of energy and environmental loads related to a process or activity, carried out by identifying energy and materials used and wastes released into the environment. The assessment includes the entire life cycle of the process or activity, including the extraction and transportation of raw materials, manufacture, transportation, distribution, use, reuse, recycling and final disposal". 
LCA, therefore, is fundamentally a quantitative technique for determining the input factors (raw materials, use of resources, energy, etc.) and output (waste, emissions, etc.) from the cycle of life of each product by assessing the environmental impacts. In our case, the approach is first of quality, and then an overview will be given on the quantity, given that the results have been obtained from European based database, recalculating the values for Costa Rica.

The goal of the analysis is to evaluate the environmental impacts of two processes for the production of Sodium Hypochlorite (a low-technology process with OSEC and an industrial process): the benefits of local production can be evaluated through the following simplified LCA process.

First of all both processes should be defined; then the set of operations that characterize them, using a block diagram that illustrates the material flows. Two main assumptions have been taken in consideration:

- The emissions related to the OSEC process are the same as the production of hypochlorite with the industrial process, as shown in Figure 1;

- The empty bottles of Sodium Hypochlorite are recycled, meaning zero emissions and waste.

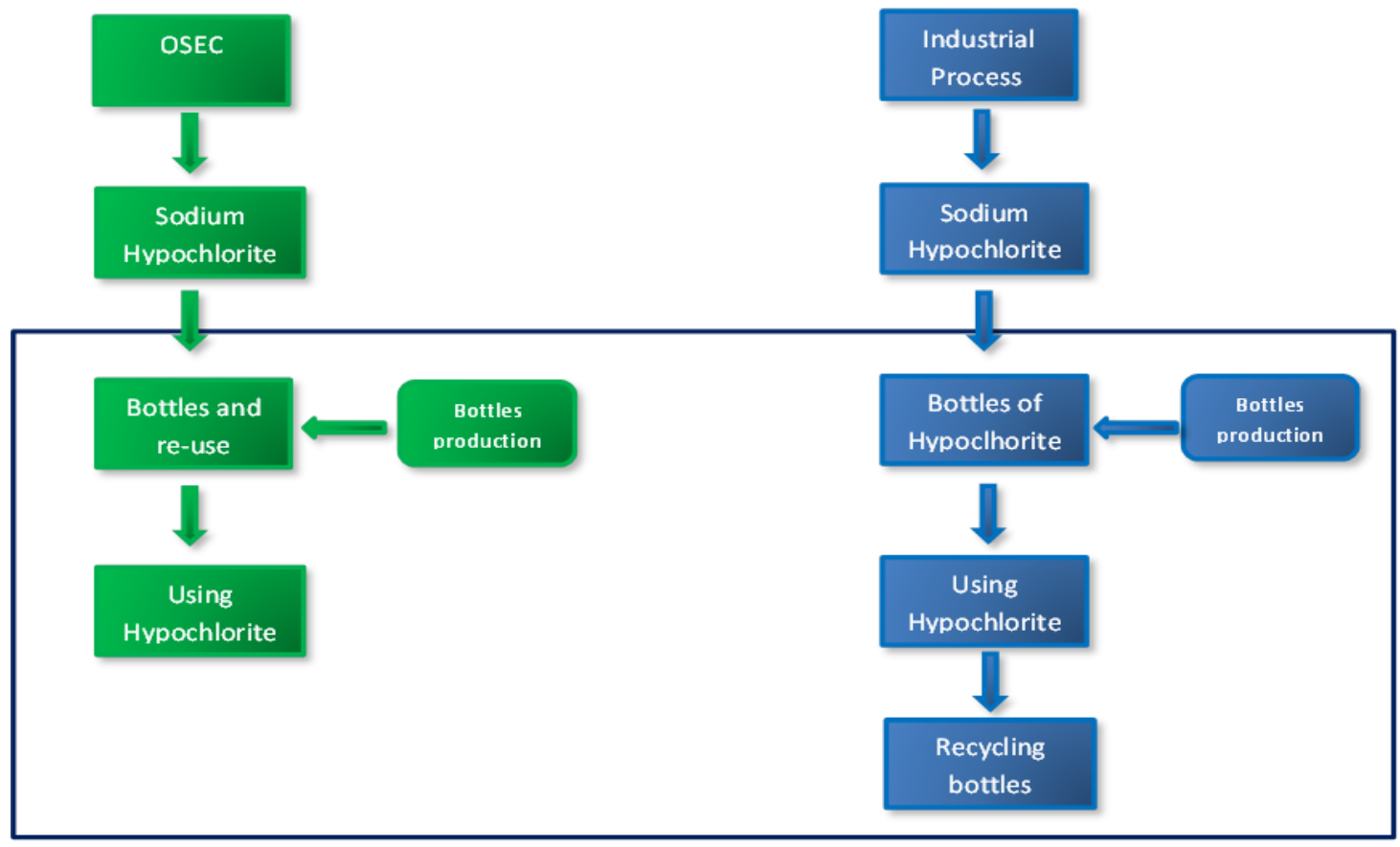

Figure 1. Flowchart of production and use of Sodium Hypochlorite On Site (Green Flow Chart) - Industrial process (Blue Flow Chart);

$\mathrm{T}=$ Transportation;

Inside the blue box = phases considered in LCA analysis;

The analysis has been applied to a cooperative society (CoopeSilencio) composed of some 100 families in Costa Rica. The computation time is estimated by 1 year.

\section{THE INDUSTRIAL PRODUCTION OF SODIUM HYPOCHLORITE PROCESS}

A family consumes an average of 5 litres per month of chlorine at a concentration of about $4.7 \%$, or 500 litres per month for an average of 100 families. With 1-liter bottles of chlorine, the result is 500 bottles of chlorine per month, or 6,000 bottles per year. The average weight of a plastic bottle of $1 \mathrm{~L}$ is $45 \mathrm{~g}$ (considering the white reinforced plastic 
bottles used specifically for chlorine, to prevent the decay of chlorine exposure to heat and light), resulting in a total weight of $270 \mathrm{~kg}$ of empty plastic bottles per year.

Our functional unit will be: $1 \mathrm{~kg}$ of plastic bottles $(1 \mathrm{~kg}$ of PET Polyethylene Terephthalate). The energy of the LCA sheets refers to a European energy mix typical of the European countries [33, 34].

Plastic bottle production requires a total energy amount of $79.8 \mathrm{MJ} / \mathrm{kg}$. The transport distance is assumed to be $20 \mathrm{~km}$ from the production site of the bottles to the filling facility (empty bottles) and an average of $150 \mathrm{~km}$ from the filling facility to the final user (full bottles). The End of life is considered as a Zero-emissions recycling process.

\section{ON-SITE PRODUCTION OF SODIUM HYPOCHLORITE PROCESS (OSEC) AND COMPARISON BETWEEN THE TWO PROCESSES}

Regarding the production process of PET, it is important to consider that the bottles are produced only once a year, as they can be easily reused and filled with new hypochlorite produced on site for 12 months. So the total weight of bottles will be $22.5 \mathrm{~kg}$ per year. Plastic bottle production requires a total energy amount of $79.8 \mathrm{MJ} / \mathrm{kg}$. The transport distance is assumed to be an average of $150 \mathrm{~km}$ from the production site to the final user (empty bottles). The End of life is considered as a Zero-emissions recycling process.

The first step is to analyse the energy situation in Costa Rica. The domestic supply of energy in Costa Rica in 2010 shows 93\% from renewable energy and 7\% from petroleum (76\% hydropower, $12 \%$ geothermal energy, $4 \%$ from wind power and $1 \%$ from other sources) [35].

The second step is to evaluate total energy for the production of PET bottles and transportation (a round trip was taken into consideration, with a full truck going and an empty one going back.).

The total annual emissions, due at the production of PET and the transport, are listed in Table 3.

Table 3. Emissions (On Site/Industrial process)

\begin{tabular}{|c|c|c|c|}
\hline \multicolumn{2}{|c|}{$\begin{array}{l}\text { Industrial process: } \\
\text { Production of } 270 \mathrm{~kg} \text { PET+ transport }\end{array}$} & \multicolumn{2}{|c|}{$\begin{array}{c}\text { Process on site: } \\
\text { Production of } 22.5 \mathrm{~kg} \text { PET }+ \text { transpor }\end{array}$} \\
\hline \multicolumn{2}{|c|}{ Greenhouse effect } & \multicolumn{2}{|c|}{ Greenhouse effect } \\
\hline $\mathrm{CO}_{2}$ & $378.5 \mathrm{~kg}$ & $\mathrm{CO}_{2}$ & $27.43 \mathrm{~kg}$ \\
\hline $\mathrm{CO}$ & $0.92 \mathrm{~kg}$ & $\mathrm{CO}$ & $0.071 \mathrm{~kg}$ \\
\hline $\mathrm{CH}_{4}$ & $2.2 \mathrm{~kg}$ & $\mathrm{CH}_{4}$ & $0.18 \mathrm{~kg}$ \\
\hline $\mathrm{N}_{2} \mathrm{O}$ & $0.8 \mathrm{~g}$ & $\mathrm{~N}_{2} \mathrm{O}$ & $6.1 \mathrm{mg}$ \\
\hline \multicolumn{2}{|c|}{ Acidification } & \multicolumn{2}{|c|}{ Acidification } \\
\hline $\mathrm{SO}_{2}$ & $9.72 \mathrm{~kg}$ & $\mathrm{SO}_{2}$ & $0.15 \mathrm{~kg}$ \\
\hline $\mathrm{NO}_{2}$ & $0.81 \mathrm{~kg}$ & $\mathrm{NO}_{2}$ & $0.07 \mathrm{~kg}$ \\
\hline $\mathrm{NO}_{\mathrm{x}}$ & $0.8 \mathrm{~kg}$ & $\mathrm{NO}_{\mathrm{x}}$ & $5.7 \mathrm{~g}$ \\
\hline \multicolumn{2}{|c|}{ Photochemical oxidant formation } & \multicolumn{2}{|c|}{ Photochemical oxidant formation } \\
\hline $\mathrm{C}_{2} \mathrm{H}_{4}$ & $0.19 \mathrm{~g}$ & $\mathrm{C}_{2} \mathrm{H}_{4}$ & $16 \mathrm{mg}$ \\
\hline $\mathrm{C}_{6} \mathrm{H}_{6}$ & $0.72 \mathrm{~g}$ & $\mathrm{C}_{6} \mathrm{H}_{6}$ & $25 \mathrm{mg}$ \\
\hline $\mathrm{C}_{7} \mathrm{H}_{8}$ & $0.23 \mathrm{~g}$ & $\mathrm{C}_{7} \mathrm{H}_{8}$ & $13 \mathrm{mg}$ \\
\hline $\mathrm{C}_{3} \mathrm{H}_{6}$ & $0.15 \mathrm{~g}$ & $\mathrm{C}_{3} \mathrm{H}_{6}$ & $12 \mathrm{mg}$ \\
\hline \multicolumn{2}{|c|}{ Eutrophication } & \multicolumn{2}{|c|}{ Eutrophication } \\
\hline $\mathrm{PO}_{4}{ }^{3-}$ & $0.073 \mathrm{~g}$ & $\mathrm{PO}_{4}^{3-}$ & $6 \mathrm{mg}$ \\
\hline $\mathrm{NH}_{3}$ & $0.49 \mathrm{~g}$ & $\mathrm{NH}_{3}$ & $29 \mathrm{mg}$ \\
\hline $\mathrm{NO}_{3}^{-}$ & $0.35 \mathrm{~g}$ & $\mathrm{NO}_{3}^{-}$ & $29 \mathrm{mg}$ \\
\hline
\end{tabular}


The results are illustrated in the graph below (Figure 2). The scale is logarithmic, due to the different order of magnitude of the amount of substances under study.

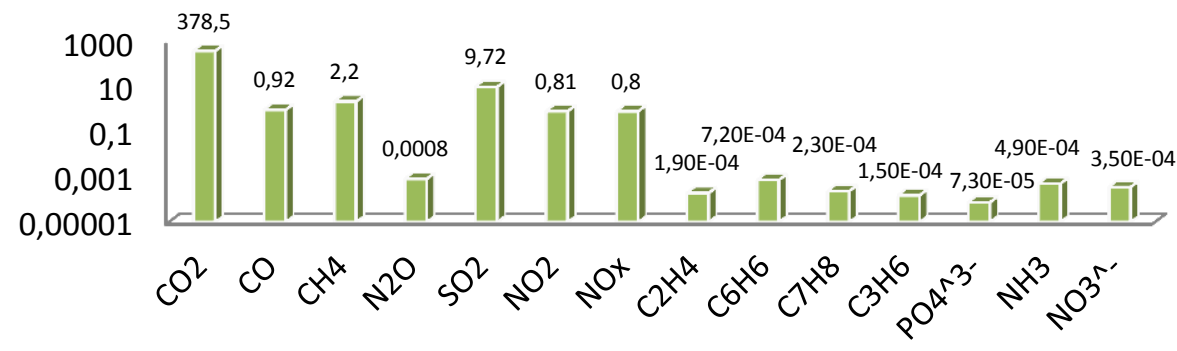

\section{Industrial Production}

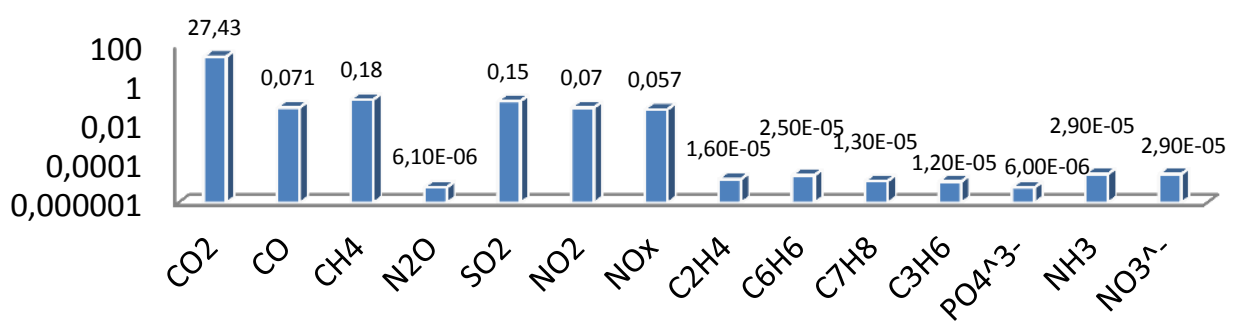

\section{On Site Production}

Figure 2. Comparison of Emissions (in kg) between "On site" and "Industrial process" (Logarithmic scale base 10)

To show the differences between the two processes, all the values are referred to the on-site process in the Table 4.

Table 4. N Factor, increase of industrial emissions compared to those on site

\begin{tabular}{cc}
\hline \multicolumn{1}{c}{$\begin{array}{c}\text { N factor: } \\
\text { Increase of industrial emissions compared to those on site }\end{array}$} \\
\hline & Greenhouse effect \\
\hline $\mathrm{CO}_{2}$ & $\mathrm{~N}=14$ \\
$\mathrm{CO}$ & $\mathrm{N}=13$ \\
$\mathrm{CH}_{4}$ & $\mathrm{~N}=12$ \\
$\mathrm{~N}_{2} \mathrm{O}$ & $\mathrm{N}=140$ \\
\hline & \\
\hline $\mathrm{SO}_{2}$ & $\mathrm{~N}=65$ \\
$\mathrm{NO}_{2}$ & $\mathrm{~N}=12$ \\
$\mathrm{NO}_{\mathrm{x}}$ & $\mathrm{N}=140$ \\
\hline & Acidification \\
\hline $\mathrm{C}_{2} \mathrm{H}_{4}$ & $\mathrm{~N}=12$ \\
$\mathrm{C}_{6} \mathrm{H}_{6}$ & $\mathrm{~N}=29$ \\
$\mathrm{C}_{7} \mathrm{H}_{8}$ & $\mathrm{~N}=18$ \\
$\mathrm{C}_{3} \mathrm{H}_{6}$ & $\mathrm{~N}=12$ \\
\hline & \\
\hline $\mathrm{PO}_{4}{ }^{\wedge} 3-$ & $\mathrm{N}=12$ \\
$\mathrm{NH}_{3}$ & $\mathrm{~N}=17$ \\
$\mathrm{NO}_{3}^{\wedge}$ & $\mathrm{N}=12$ \\
\hline
\end{tabular}


It basically shows that the emissions related to production phase $\left(\mathrm{NO}_{2}, \mathrm{C}_{2} \mathrm{H}_{4}, \mathrm{C}_{3} \mathrm{H}_{6}\right.$, et al.) increased by a factor of 12 , only those related to transport $\left(\mathrm{N}_{2} \mathrm{O}, \mathrm{NO}_{\mathrm{x}}\right)$ by a factor of 140 and other different factors depending on the weight they have in the production and transport.

\section{CHARACTERIZATION: QUANTITATIVE ANALYSIS}

After completing the inventory phase, the method of characterization allows to determine a homogeneous and quantitative contribution of each emission. This phase allows defining the values of the category indicators that have previously been defined for each effect considered:

- Greenhouse effect: the quantities of greenhouse gases under analysis are expressed in $\mathrm{kg}$ of $\mathrm{CO}_{2}$ equivalents through operation of standardization based on "global warming potentials" (GWPs, global warming potentials). GWP $i$ indicates the global warming potential of substance $i$, and the resulting total potential is given by:

$$
\mathrm{GWP}=\Sigma \mathrm{GWP}_{i} \times m_{i}
$$

with $m_{i}$ mass of the $i$-th substance;

The GWP is evaluated for various periods of exposure called "time-horizon" (generally 100 years; in practice the GWP is a measure of the potential contribution that in 100 years a substance causes the greenhouse effect than that caused by the same weight of $\mathrm{CO}_{2}$;

- Acidification: factors are used to standardize reporting $\mathrm{kg}$ of $\mathrm{SO}_{2}$ equivalent through the "acidification potential". The preliminary operation of this standardization is by aggregating the emissions potentially acidic $\left(\mathrm{SO}_{2}, \mathrm{NO}_{\mathrm{x}}\right)$ according to their tendency to form $\mathrm{H}^{+}$ions. The acidification potential of a substance is defined as the relationship between the number of ions $\mathrm{H}^{+}$equivalent potential per unit mass of the substance and the number of potential ion equivalent $\mathrm{H}+$ per unit mass of $\mathrm{SO}_{2}$;

- Formation of oxidizing photochemical: in this case the category indicator is ethylene $\left(\mathrm{C}_{2} \mathrm{H}_{4}\right)$. The characterization factors are expressed in $\mathrm{kg}$ of $\mathrm{C}_{2} \mathrm{H}_{4}$ equivalents per $\mathrm{kg}$ of the relevant substance;

- Eutrophication: the category indicator is the phosphate ion. The characterization factors are in $\mathrm{kg} \mathrm{PO}_{4}{ }^{3-}$ equivalents per kilogram of its substance.

Table 5 shows the values of the indicators for the industrial and on site process.

Table 5. Characterization of PET and transport (On Site/Industrial process)

\begin{tabular}{cc}
\hline $\begin{array}{c}\text { Industrial production of 270 kg PET + } \\
\text { transport (annual) }\end{array}$ & $\begin{array}{c}\text { Production on site of 22.5 kg PET + } \\
\text { transport (annual) }\end{array}$ \\
\hline Greenhouse effect $\left(\mathrm{GWP} \mathrm{g} \mathrm{CO}_{2}\right)$ & Greenhouse effect $(\mathrm{GWP} \mathrm{g} \mathrm{CO})$ \\
\hline 426.600 & 31.370 \\
\hline Acidification $\left(\mathrm{g} \mathrm{SO}_{2}\right)$ & Acidification $\left(\mathrm{g} \mathrm{SO}_{2}\right)$ \\
\hline 12.500 & 223 \\
\hline Photochemical oxidant formation $\left(\mathrm{g} \mathrm{C}_{2} \mathrm{H}_{4}\right)$ & Photochemical oxidant formation $\left(\mathrm{g} \mathrm{C}_{2} \mathrm{H}_{4}\right)$ \\
\hline 1.1 & 0.06 \\
\hline Eutrophication $\left(\mathrm{g} \mathrm{PO}_{4}{ }^{3-}\right)$ & Eutrophication $\left(\mathrm{g} \mathrm{PO}_{4}{ }^{3-}\right)$ \\
\hline 0.3 & 0.02 \\
\hline
\end{tabular}


The same values are shown graphically in Figure 3 on a logarithmic scale.

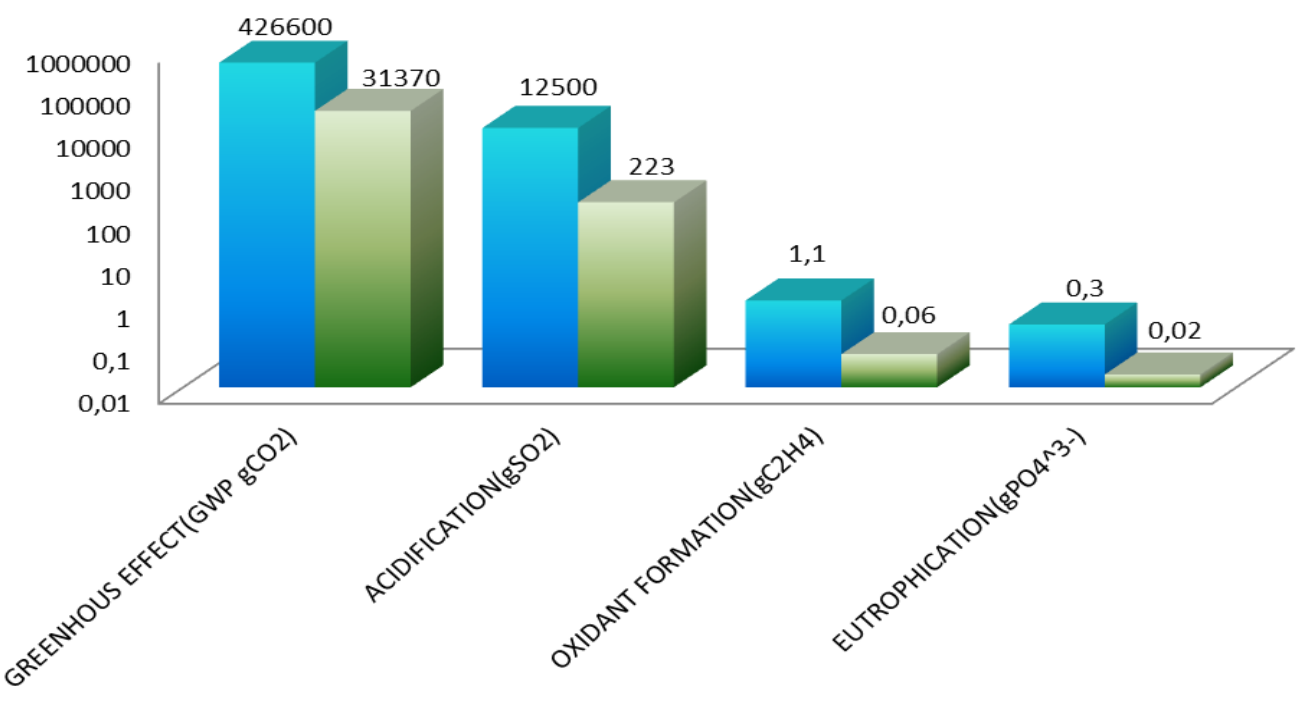

- On Site Production Industrial Production

Figure 3. Comparison of Emissions (in g) between "On Site" and "Industrial process" (Logarithmic scale base 10)

It is evident that the major effect is the greenhouse effect and acidification. It should however be noted that we have considered only some of the most significant values, so the goodness of our study is qualitative rather than quantitative.

The industrial process emissions of pollutants are much higher than those of the on-site process as shown in Table 6.

Table 6. N Factor, increase of Characterization industrial emissions compared to those on site

\begin{tabular}{c}
\hline $\begin{array}{c}\text { Characterization } \\
\text { N factor of increase of industrial emissions compared to those on site }\end{array}$ \\
\hline Greenhouse effect $\left(\mathrm{g} \mathrm{CO}_{2}\right)$ \\
\hline $\mathrm{N}=14$ \\
\hline Acidification $\left(\mathrm{g} \mathrm{SO}_{2}\right)$ \\
\hline $\mathrm{N}=56$ \\
\hline Photochemical oxidant formation $\left(\mathrm{g} \mathrm{C}_{2} \mathrm{H}_{4}\right)$ \\
\hline $\mathrm{N}=18$ \\
\hline Eutrophication $\left(\mathrm{g} \mathrm{PO}_{4}{ }^{3-}\right)$ \\
$\mathrm{N}=15$ \\
\hline
\end{tabular}

The factor $\mathrm{N}=56$ "out of scale" compared to the average factor $\mathrm{N}=16$ of the other emissions, is due to the fact that the $\mathrm{SO}_{2}$ has a pollutant emission 7 times less than that of $\mathrm{CO}_{2}$ as regards the transport compared to pollutant emissions as much as 300 times less than that of $\mathrm{CO}_{2}$ as regards the production of PET.

We have then demonstrated with a simplified LCA study the goodness of a process of self-production process on site compared to industrial process production.

\section{RESULTS}

The analysis performed on the socio-economic-environmental, health and water supply issues, in the communities of the four countries considered in this study, has 
shown that the production of Sodium Hypochlorite on site can have a significant impact on health conditions in preventing communicable diseases and on individual and collective behaviour.

The OSEC technology produces Sodium Hypochlorite at a price, estimated 10 to 15 times cheaper than the market prices and lends itself, therefore, to effectively pursue social objectives such as water purification and disinfection, improvement of hygienic conditions and job creation in rural and peri-urban low-income communities.

The only operating cost in producing the hypochlorite is the purchase of salt, which, among other things, presents no particular problems of transport and storage and is available everywhere.

As regards the environmental impact, the OSEC technology is a self-production process on site, which has less impact than any industrial process.

In addition, the OSEC system is very simple to use, and through monitoring systems and automatic dilution is possible for anyone to check the functioning optimally. The manual operations are limited to the addition of appropriate amounts of salt and regular cleaning and maintenance of the machinery.

Therefore, the most appropriate form of enterprise is a small business based on the Social Business model and not just a small business activity resulting from a microcredit. In fact the overall cost of the OSEC system is of about 4,000.00 EUR and could not be sustainable for a single individual or a five person group belonging to low-income communities, following the usual microcredit structure.

Social Business seems to be the best option to launch a small wealth enterprise of production of Sodium Hypochlorite. In fact the financing of Start-up Company will be obtained either through a donation or through a loan from a trust fund (or other similar financing mechanisms). In the second case, the company's business plan must include a plan for repayment of the original loan.

In order to ensure the viability of the project, other interventions need to be taken into consideration:

- Technical training of local people to produce Sodium Hypochlorite through the OSEC system;

- Technical assistance during the start-up and capacity-building support to the personnel who will manage the economic aspects of the company;

- The launch, at the same time, of an educational program on the use of Sodium Hypochlorite and on the behaviours at individual and community levels aimed at preventing and reducing the risk of transmitting infectious diseases directed to the communities in which the Sodium Hypochlorite will be sold at low cost;

- The establishment of a sellers group of the Sodium Hypochlorite within the community or in neighbouring communities.

\section{CONCLUSION}

The study has evaluated the opportunity of applying the Social Business model in the water and sanitation sector in the rural areas of Africa and Latin America. It has demonstrated the possibility to ensure a better sustainability of the enterprises over the time and guarantee incomes for the people involved. The type of business, the type of financing and the type of management would vary according to the context and has to be created based on the ability and real needs of the communities where the project is implemented [36].

OSEC applications in these contexts can demonstrate the mutually reinforcing role played by the water and sanitation and the Social Business sector. The sanitation loan sector shows high potential as regards both retail loans and SMEs type loans for water 
supply [37]. It has a considerable scope and can increase health and high-quality water supply benefits, while freeing up public resources for other projects. The social impact of this technology can be very high and solve many problems related to the disinfection of water and hygienic behaviour of disadvantaged people in the East Africa and Central America.

The study has demonstrated the versatility of the technology presented and its adaptability to different contexts and needs that can vary from water disinfection, improvement of health and sanitation standards.

\section{NOMENCLATURE}

$\mathrm{C}_{2} \mathrm{H}_{4}$ - Ethylene

$\mathrm{C}_{3} \mathrm{H}_{6}$ - Propene

$\mathrm{C}_{6} \mathrm{H}_{6}$ - Benzene

$\mathrm{C}_{7} \mathrm{H}_{8}$ - Toluene

$\mathrm{CH}_{4}$ - Methane

$\mathrm{CO}$ - Carbon monoxide

$\mathrm{CO}_{2}$ - Carbon dioxide

GWP - Global Warming Potentials

LCA - Life Cycle Assessment

$\mathrm{N}_{2} \mathrm{O}$ - Nitrous oxide

$\mathrm{NaCl}$ - Sodium Chloride

$\mathrm{NaOCl}$ - Sodium Hypochlorite

$\mathrm{NH}_{3}-$ Ammonia

$\mathrm{NO}_{2}$ - Nitrogen dioxide

$\mathrm{NO}_{3}$ - Nitrate ion

$\mathrm{NO}_{\mathrm{x}}$ - Nitrogen oxides

OSEC - On Site Electro Chlorination

PET - Polyethylene Terephthalate

$\mathrm{PO}_{4}{ }^{3}$ - Phosphate ion

PV System - Photovoltaic System

$\mathrm{SO}_{2}$ - Sulphur dioxide

\section{Acknowledgements}

Special acknowledgement to Ph.D. candidate Marco Ricci. 


\section{REFERENCES}

1. Mehta, M., Assessing microfinance for water and sanitation. Exploring Opportunities for Sustainable Scaling Up, A study for the Bill \& Melinda Gates Foundation, 2008.

2. Esposto S., Micangeli A., Grego S., Sustainable Water Treatment and Chlorine Production in Emergency Conditions in South Iraq, Desalination, vol. 165, 2004., http://dx.doi.org/10.1016/j.desal.2004.06.014

3. Brent, A.C. and Pretorius, M.W., Sustainable Development and technology Management, Management of technology innovation and value creation, Sherif, $\mathrm{MH}$ and Khalil TM (eds.), Management of Technology, 2, pp 185-204, New Jersey: World Scientific, 2008.

4. Karunakaran, C.E., Jayaraj, G., Venkiteswaran, V., and Nazar, Micro-enterprise Development with Innovative Community and Market Linkages, Seminar on Decentralisation, Sustainable Development and Social Security, pp 53-76, 2002.

5. Grego, S., Micangeli, A., Esposto, S., Water purification in the Middle East crisis: A survey on WTP and CU in Basrah (Iraq) area within a research and development program, Desalination, 165 (SUPPL.), pp 73-79, 2004., http://dx.doi.org/10.1016/j.desal.2004.06.007

6. Saywell, D., Microcredit for Sanitation, WELL Resource Centre for Water, Sanitation and Environmental Health, 2006.

7. Micangeli A., Ianuzzo N., Esposto S., A Chlorine Self-Production Plant Solution for Effluent Water to be Used in Irrigation in Gaza Strip, in J. Kauffman, K.-M. Lee (eds.), Handbook of Sustainable Engineering, pp 117-135, http://dx.doi.org/10.1007/978-1-4020-8939-8_88

8. Micangeli, A., Esposto, S., Post-earthquake rehabilitation of the rural water systems in Kashmir's Jehlum Valley, 2010, Disasters, 34 (3), pp 684-694, http://dx.doi.org/10.1111/j.1467-7717.2010.01164.x

9. Micangeli A., Cataldo M., Micro Hydro in Emergency Situations: A Sustainable Energy Solution at La Realidad (Chiapas, Mexico), in J. Kauffman, K.-M. Lee (eds.), Handbook of Sustainable Engineering, pp 164-179, Springer, 2013, http://dx.doi.org/10.1007/978-1-4020-8939-8_87

10. Micangeli A.,Grego S., Esposto S., Sustainable Rehabilitation of Water Infrastructures in Southern Iraq After the Second Gulf War, in J. Kauffman, K.-M. Lee (eds.), Handbook of Sustainable Engineering, pp 211- 245, Springer, 2013. http://dx.doi.org/10.1007/978-1-4020-8939-8_86

11. Gualberti G., Alves L., Micangeli A., Carvalho M.G., Electricity Privatizations in Sahel: A U-Turn?, Energy Policy, vol. 37, 2009., http://dx.doi.org/10.1016/j.enpol.2009.05.018

12. Littlefield, E., Murduch, J., and Hashemi, S., Is Microfinance an Effective Strategy to Reach the Millennium Development Goals?, CGAP - Consultative Group to Assist the Poor, 2003.

13. African Development Bank Group, African Development Report 2008/2009

14. Kates, R., Sustainability Science, World Academies Conference "Transition to Sustainability in 21th Century", May 5/18/2000, Tokyo, Japan, 2000.

15. Theocharis, D.T. and Yeoryios, A.S., The sustainable diffusion of renewable energy technologies as an example of an innovation-focused policy, Science Direct, $\begin{array}{llllll}\text { Technovation } 25, & \text { pp } & 753 \quad 761, & \text { 2005, }\end{array}$ http://dx.doi.org/10.1016/j.technovation.2003.12.003

16. United States Agency for International Development (USAID), A guide for assessing the impact of microenterprise services at the individual level, 1997. 
17. Burns, M., Audouin, M. and Weaver, A., Advancing Sustainability science in South Africa, South Africa Journal of Science, September/October, 2006.

18. Comisión Centroamericana de Ambiente y Desarrollo (CCAD) de la Secretaría de Integración Económica (SICA). Plan Ambiental de la Región Centroamericana (PARCA), 2010-2014. San Salvador, 2010

19. Micangeli, A., Michelangeli, E., Naso, V., Sustainability after the thermal energy supply in emergency situations: The case study of Abruzzi Earthquake (Italy), Sustainability, Switzerland, pp. 3513-3525, 2013., http://dx.doi.org/10.3390/su5083513

20. Steinfeld, J.I. - Takashi, M., Education for sustainable development: the challenge of trans-disciplinarity, Sustainable Science - 4: 1-2, 2009, http://dx.doi.org/10.1007/s11625-009-0072-6

21. Micangeli A., Costantini I., Fernandez S., Technology for Autonomy and Self-Reliance: International Technology Transfer for Social Movements. In: Sparking a Worldwide Energy Revolution, 2010.

22. Yunus. M., Building Social Business, The new kind of capitalism that serves humanity's most pressing needs, 2010.

23. Baldo G., Marino M., Rossi S., Analisi del ciclo di vita, edizione ambiente, 2008.

24. Sisinni, M., Carlo, A.D., Bocci, E., Micangeli, A., Naso, V., Hydrogen-rich gas production by sorption enhanced steam reforming of woodgas containing TAR over a commercial $\mathrm{Ni}$ catalyst and calcined dolomite as $\mathrm{CO}_{2}$ sorbentx, Energies, pp. 3167-3181, 2013., http://dx.doi.org/10.3390/en6073167

25. African Development Bank, Financing of Sustainable Energy Solutions, Committee of Ten Policy Brief, n.3, 2010.

26. Secretaría de Salud, Estados Unidos Mexicanos, Programa Nacional de Salud 2007-2012. Por un México sano: construyendo alianzas para una mejor salud, 2007.

27. Banco Mundial, Estudio Programático Regional para el Sector Energético Módulo de Aspectos Generales y Opciones, ESMAP, The Energy Managment Assistance Program. America Central. January, 2010.

28. Cumbre Mundial sobre el Desarrollo Sostenible en Johannesburg, Energy and Environment Partnership (EPP) con América Central. - Medina, L., La Empresa, el Medio Ambiente y la Responsabilidad Social. Costa Rica, 2002.

29. Newman, J., Pradhan, M., Rawlings, L.B., Ridder ,G., Coa, R., and Evia, J.L., An impact evaluation of Education, Health, and Water Suppy Investments by the Bolivian Social Investment Fund, The World Bank Economic Review, vol. 16, no. 2, pp 241- 274, 2002., http://dx.doi.org/10.1093/wber/16.2.241

30. Shuval, H.I., Tilden, R.L., Perry, B.H. and Grosse, R.N., Effect of investments in water supply and sanitation on health status: a threshold-saturation theory, Bulletin of the World Health Organization, 59 (2): pp 243-248, 1981.

31. United Nations Security Council, Report of the Secretary-General on the situation concerning Western Sahara, 2011.

32. Borello D., Corsini A., Delibra G., Evangelisti S., Micangeli A., Experimental and computational investigation of a new solar integrated collector storage system, Applied Energy, 97, pp 982-989, 2012., http://dx.doi.org/10.1016/j.apenergy.2012.01.026

33. Micangeli A., Evangelisti S., Sbordone D., Alternative Energy: Solar Thermal Energy, Encyclopedia of Environmental Management. Taylor and Francis: New York, pp 241-257, 2013.

34. Micangeli A., Flumeri F., Federici S., Belardinelli M.O., User Satisfaction with Assistive Technologies: Application of the ICF-Checklist and Quest on a Group of Afghan Disabled, pp 54, Cognitive Processing, 2003. 
35. Dell'Era A., Zuccari F., Santiangeli A., Fiori C., Micangeli A., Orecchini F., Energy optimisation and layout of a membrane-free OSEC system for the hypochlorite self-production in Developing Countries, Energy Conversion and Management, 75, pp. 446-452, 2013., http://dx.doi.org/10.1016/j.enconman.2013.06.046

36. Sexto Plan Nacional de Energia de Costa Rica, MINAET Ministerio de Ambiente Energia y Telecomunicacciones, DSE Direccion Sectorial de Energia, Diciembre, 2011.

37. Varley, R.C.G., Financial Services and Environmental Health: Household Credit for Water and Sanitation, Applied Study No. 2, Environmental Health Project, Environmental Health Division, Office of Health and Nutrition, USAID, Washington DC, USA, 1995.

38. Micangeli A., Evangelisti S., Sbordone D., Alternative Energy: Hydropower. In Encyclopedia of Environmental Management, Taylor and Francis, New York, pp 201-214, 2013. 